\title{
Application of Gliricidia sepium leaves compost as depuration agent of leads (Pb) in the body organ of red tilapia Oreochromis sp.
}

\section{Penggunaan kompos daun gamal Gliricidia sepium sebagai pendepurasi timbal $(\mathbf{P b})$ pada organ nila merah Oreochromis sp.}

\author{
Robin', Eddy Supriyono ${ }^{2 *}$, Kukuh Nirmala², Enang Harris², Ridwan Affandi², \\ Dedi Jusadi
}

\author{
${ }^{1}$ Jurusan Budidaya Perairan, Fakultas Pertanian Perikanan dan Biologi, Universitas Bangka Belitung \\ Jalan Kampus Peradaban, Kampus Terpadu UBB Balunijuk, Merawang, Kepulauan Bangka Belitung 33172 \\ ${ }^{2}$ Departemen Budidaya Perairan, Fakultas Perikanan dan Ilmu Kelautan, Institut Pertanian Bogor \\ ${ }^{3}$ Departemen Manajemen Sumberdaya Perairan, Fakultas Perikanan dan Ilmu Kelautan, Institut Pertanian Bogor \\ Jalan Agatis, Kampus IPB Dramaga Bogor, Jawa Barat 16680 \\ *E-mail: eddy_supriyono@yahoo.com
}

\begin{abstract}
This study was aimed to perform depuration of $\mathrm{Pb}$ contained in tilapia body. The experiments were conducted in aquarium using compost of Gliricidia sepium leaves at different concentrations i.e. $10 \mathrm{~g} / \mathrm{L}, 20 \mathrm{~g} / \mathrm{L}, 30 \mathrm{~g} / \mathrm{L}, 40 \mathrm{~g} / \mathrm{L}$, and $0 \mathrm{~g} / \mathrm{L}$ (control). The result showed that $\mathrm{Pb}$ level in fish muscle immersed with compost of Gliricidia leaves at a dose of $30 \mathrm{~g} / \mathrm{L}$ for five days successfully decreased to a safe limit for human consumption $(<0.3 \mathrm{mg} / \mathrm{kg})$. However, decrease of $\mathrm{Pb}$ level in fish liver and kidney to finally reach the safe limit required seven days. Decreasing level of lead in the organs of experimental fish along with the increasing level of $\mathrm{Pb}$ in compost and culture media indicated that $\mathrm{Pb}$ accumulated in fish were released into the culture media by compost through chelation process. To conclude, compost of G. sepium leaves can be used as the material for depuration of $\mathrm{Pb}$ in the body of tilapia
\end{abstract}

Keywords: humic acid, fulvic acid, depuration, Gliricidia leaves, lead, red tilapia

\begin{abstract}
ABSTRAK
Penelitian ini bertujuan untuk mendepurasi $\mathrm{Pb}$ yang terkandung di tubuh ikan nila. Percobaan dilakukan di dalam akuarium menggunakan kompos daun gamal pada konsentrasi $10 \mathrm{~g} / \mathrm{L}, 20 \mathrm{~g} / \mathrm{L}, 30 \mathrm{~g} / \mathrm{L}, 40 \mathrm{~g} / \mathrm{L}$, dan $0 \mathrm{~g} / \mathrm{L}$ (kontrol). Hasil penelitian menunjukkan bahwa, $\mathrm{Pb}$ di daging ikan yang direndam dengan kompos daun gamal pada konsentrasi $30 \mathrm{~g} / \mathrm{L}$ selama lima hari, kadarnya menurun hingga batas aman untuk dikonsumsi manusia $(<0,3 \mathrm{mg} /$ $\mathrm{kg}$ ). Penurunan $\mathrm{Pb}$ di hati dan ginjal untuk mencapai kadar aman membutuhkan waktu yang lebih lama, yakni tujuh hari. Seiring dengan menurunnya kadar $\mathrm{Pb}$ dalam organ ikan uji, kisaran $\mathrm{Pb}$ dalam kompos dan media budidaya meningkat, menunjukkan bahwa $\mathrm{Pb}$ dari tubuh ikan dilepaskan ke media budidaya dan terjadi proses khelat oleh kompos. Dengan demikian, kompos daun gamal bisa digunakan sebagai bahan pendepurasi $\mathrm{Pb}$ dari tubuh ikan nila.
\end{abstract}

Kata kunci: asam humat, asam fulvik, depurasi, daun gamal, timbal, nila merah

\section{INTRODUCTION}

Kolong is a tin ( $\mathrm{Sn})$ post-mining lake in Bangka Belitung province (Babel). In general, the kolong depth ranges from 2-50 $\mathrm{m}$ in length and approximately of 75-200 $\mathrm{m}$ in width (Henny \& Evi, 2009). Nowadays, Babel province has been in a period of post-mining. As one alternative to drive economic of community in the post-mining area, Babel provincial government promotes freshwater aquaculture sector in kolong. There are at least 3,712.65 hectares of potential kolong for aquaculture activities (Sujitno, 2007). However, heavy metals such as lead $(\mathrm{Pb})$ are always found in the water and sediments of kolong in an amount exceeding safe level for human consumption.

The content of $\mathrm{Pb}$ in the muscle of tilapia with length of 20-26 cm in kolong restocking reached $4 \mathrm{mg} / \mathrm{kg}$ (dry weight) while the content of $\mathrm{Pb}$ in wild small fish Punctius sp. found in kolong restocking amounted to $73.27 \mathrm{mg} / \mathrm{kg}$ (dry weight) (Henny, 2011). The content of Pb was very high 
if compared to the content of $\mathrm{Pb}$ in tilapia found in Cirata Dam that was only about 0.003 to 0.065 $\mathrm{mg} / \mathrm{kg}$ (Priyanto et al., 2008). According to the previous research, accumulation of $\mathrm{Pb}$ in red tilapia muscle maintained for three months in kolong which has been established for more than ten years ( $>10$ years) and less than ten years were $0.188 \mathrm{mg} / \mathrm{kg}(>10$ years) and $24.33 \mathrm{mg} / \mathrm{kg}(<10$ years), respectively. Whereas, the quality standard of maximum $\mathrm{Pb}$ content in processed fish meat is $0.3 \mathrm{mg} / \mathrm{kg}$ (ISO, 2009). Therefore, it is necessary to conduct a depuration process to eliminate $\mathrm{Pb}$ before the fish is released into the market.

Availability of Gliricidia sepium leaves is relatively abundant in Babel province. Biomass of gamal leaves is quick and easy to decompose, making the leaves of this plant as a great potential material to be used. According to Kucasoy and Guvener (2009), decomposition product of green leaves (compost) is one of materials that can be used to minimize heavy metals in the water of culture media. Compost minimizes heavy metals through ion exchange, adsorption and chelate formation. The substance of compost (fulvic acid, humic acid, and humin) is able to adsorb heavy metal complex via cation exchange, chelate formation, and electrostatic bonding (Hermana $\&$ Nurhayati, 2010). Based on preliminary test results, the composition of Gliricidia leaves after composted for 30 days contain $3.55 \%$ humic acid and $0.36 \%$ fulvic acid. These results confirmed the findings by Prasetiyono (2013) which showed that compost of Gliricidia leaf contained 3.84\% humic acid and $6.45 \%$ fulvic acid.

Humic acid is a macromolecular material with a molecular weight (MW) of 20,000-1,360,000 $\mathrm{g} / \mathrm{mol}$, which has functional groups such as phenolic $\left(\mathrm{OH}^{-}\right)$or alcoholates $\left(\mathrm{OH}^{-}\right)$, carboxylic $\left(\mathrm{COOH}^{-}\right)$and soluble at alkaline conditions as well as have cation exchange capacity amounted to $500-700 \mathrm{mEq} / 100 \mathrm{~g}$ (Piccolo, 2002). Fulvic acid is a mixture of weak aliphatic and aromatic organic matter that dissolves at all $\mathrm{pH}$ conditions (acidic, neutral, and alkaline) and classified as micromolecular with molecular weight of 2752,110 g/mol (Nebbioso \& Alessandro, 2012). Fulvic acid has oxygen content twice than that of humic acid, yet it has low carbon and nitrogen, making it more reactive in binding metal ions (Christopher et al., 2013).

Study of the use of humic acid and fulvic acid as heavy metal chelating agent have been done. However, the use of compost of Gliricidia leaf (CGL) for chelating and depurating heavy metals especially $\mathrm{Pb}$ from the fish body has never been done. It is necessary to conduct research on the ability of CGL and its optimum concentration to depurate the accumulation of $\mathrm{Pb}$ in red tilapia organ, through the method of mixing into the culture media.

\section{MATERIALS AND METHODS}

\section{Compost of Gliricidia leaves (CGL)}

Composting was done by collecting raw materials, Gliricidia leaves. The leaves collected were green leaves and had been separated from the petiole (leafstalk). The leaves used were a mix of young and old leaves collected from Gliricidia trees with age of more than three years. Gliricidia trees whose leaves were used in this study grow in yellowish-brown podzolic soils. As much as $230 \mathrm{~kg}$ of fresh Gliricidia leaves were chopped into smaller pieces of $\pm 1 \mathrm{~cm}$. Furthermore, EM4 (effective microorganism 4) starter solution was prepared by adding $250 \mathrm{~g}$ granulated sugar and $5 \mathrm{~mL}$ of EM4 solution into $10 \mathrm{~L}$ of water. The solution then was mixed. Half of compost material that had been cut into small pieces was spread over at a thickness of $\pm 2-3 \mathrm{~cm}$ in an open container. Later, rice bran was spread over the raw material to cover the compost raw materials. Moreover, EM4 starter was sprinkled over the mixture. Subsequently, another half of compost was put on the top of the layer. EM4 starter was further sprinkled and bran was spread again. This process continued to perform until the compost raw materials was completely used.

After the mixing process was completed, the raw materials were put into a plastic bag with a capacity of $50 \mathrm{~kg}$. Monitoring of compost temperature was carried out daily by turning over the compost. The addition of water could be done if the temperature was too high and the humidity decreased. Composting was conducted for 30 days. Compost color which had already been black with a soil-like texture, temperature was in accordance with the ground water temperature, and stable $\mathrm{pH}$ within the range of 6.5-7.5 were early indication of ripe compost. Furthermore, analysis was performed to determine the level of compost ripeness, $\mathrm{C}$ and $\mathrm{N}$ content, $\mathrm{C} / \mathrm{N}$ ratio, $\mathrm{pH}$, and moisture, as well as level of humic acid and fulvic acid within the compost. Composition of CGL after being composted for 30 days is presented in Table 1.

Each compost with a weight of $10 \mathrm{~g} / \mathrm{pack}$ which was ready to use was milled finely and 
Table 1. Composition of Gliricidia leaves compost before and after composted for 30 days

\begin{tabular}{|c|c|c|}
\hline \multirow{2}{*}{ Composition } & \multicolumn{2}{|c|}{ Gliricidia leaves } \\
\hline & $\mathrm{BC}$ & $\mathrm{AC}$ \\
\hline $\mathrm{C}(\%)$ & 54.06 & 37.92 \\
\hline $\mathrm{N}(\%)$ & 3.51 & 2.99 \\
\hline $\mathrm{C} / \mathrm{N}$ ratio & 15.40 & 12.68 \\
\hline $\mathrm{pH}$ & $\mathrm{nm}$ & 7.20 \\
\hline Moisture content (\%) & $\mathrm{nm}$ & 48.89 \\
\hline Humic acid $(\%)$ & $\mathrm{nm}$ & 3.55 \\
\hline fulvic acid $(\%)$ & $\mathrm{nm}$ & 0.36 \\
\hline$[\mathrm{CEC}](\mathrm{Cmol}+/ \mathrm{kg})$ & $\mathrm{nm}$ & 80.2 \\
\hline
\end{tabular}

Note: BC: before composted; AC: after composted; nm: not measured CEC: cation exchange capacity.

then wrapped with $0.45 \mathrm{~mm}$ of thin porous cloth. Composts were immersed in the culture media according to the treatment concentration.

\section{Fish and rearing conditions}

Experimental fish used was red tilapia Oreochromis sp. obtained from fish rearing pond of Department of Aquaculture, Faculty of Fisheries and Marine Science, Bogor Agricultural University, Bogor. The average weight of each fish was $100 \mathrm{~g}$. Fish were acclimatized for one week in cement tank with the size of $2 \times 3 \mathrm{~m}$. and water continuously flowed at a flow rate of $2 \mathrm{~L} / \mathrm{s}$. During acclimatization, mortality of experimental fish should be less than $10 \%$, if the mortality was more than $10 \%$, then the acclimatization process was extended for another week. In this period, feed were given three times a day containing $28 \%$ crude protein (CP), as much as $3 \%$ of body weight. After a period of acclimation, the entire experimental fish (except control) were injected with $10 \mathrm{mg} / \mathrm{L} \mathrm{Pb}\left(\mathrm{NO}_{3}\right)^{2}$. Injection was caried out eight times with time interval between injections every two days. As much as $1 \mathrm{~mL}\left(\mathrm{NO}_{3}\right)^{2}$ was injected into the blood through vena caudalis. After eight times of injections, maintenance was continued for fifteen days in the same tank for acclimatization. Water which did not contain $\mathrm{Pb}$ flowed continuously in a flow-through model. Water flow was increased to $5 \mathrm{~L} / \mathrm{s}$. Further, $\mathrm{Pb}$ contents in the experimental fish organ were analyzed ( $\mathrm{H}-0$; before treatments were given). At the end of preparation, $\mathrm{Pb}$ content in experimental fish used was $3.026 \mathrm{mg} / \mathrm{kg}$ (dry weight) in muscle, $0.039 \pm 0.09 \mathrm{mg} / \mathrm{kg}$ in heart and $0.312 \pm 0.23 \mathrm{mg} / \mathrm{kg}$ in kidney.

The treatment in this study was started by moving fish into 15 aquaria. Each aquarium had a size of $50 \times 33 \times 30 \mathrm{~cm}$, a capacity of $40 \mathrm{~L}$, and density of 20 fish/aquarium. Fish were adapted for seven days in an experimental aquarium without treatment. The fish were given feed containing $28 \%$ crude protein (CP), as much as $3 \%$ of body weight. Each aquarium had an aeration, fish feces were cleaned every day by siphoning. On the eighth day, CGL was put into each aquarium in accordance with the concentration of the treatment. Water exchange was conducted less than $1 \mathrm{~L}$ every day for all aquarium of treatments, shortly after feces were collected.

\section{Water quality measurement}

Water quality measurements were carried out five times, namely on $\mathrm{d}-0, \mathrm{~d}-1, \mathrm{~d}-3, \mathrm{~d}-5$, and d-7 of maintenance. Measurements were carried out directly in each aquarium of treatment, with three replications. Water quality parameters measured were dissolved oxygen (DO) and water temperature, using Lutron DO-5510 Dissolved Oxygen meter, and water $\mathrm{pH}$ using Hanna HI98107 pH meter.

\section{Experimental design}

The experimental design used was completely randomized design, with four treatments and one control. The treatment applied was an administration of compost of Gliricidia leaf on culture media with several concentrations namely $0 \mathrm{~g} / \mathrm{L}$ (control), $10 \mathrm{~g} / \mathrm{L}, 20 \mathrm{~g} / \mathrm{L}, 30 \mathrm{~g} / \mathrm{L}, 40 \mathrm{~g} / \mathrm{L}$. Each treatment was repeated three times.

\section{Sampling and test parameters}

Sampling was performed randomly five times in each aquarium. The number of red tilapia 
Oreochromis sp. taken in each aquarium was three fish ( $\mathrm{n}=3$ fish). At $\mathrm{d}-0$, media water, compost, fish liver, kidney, and muscle were taken. On d-1, only water, compost, and fish muscle were taken. On d-3, water, fish liver, kidney, and muscle were taken. On d-5, water and fish muscle were taken. On d-7, water, compost, fish liver, kidney, and muscle were taken. Test parameters measured from each sample was the concentration of $\mathrm{Pb}$ and all tests were calculated in dry weight.

Destruction method used was wet method with three replications. Each organ sample of experimental fish was put into $50 \mathrm{~mL}$ beaker glass and weighed using the analytical balance. A minimum wet organ taken was as much as $10 \mathrm{~g}$. Later, dry ashing was conducted by placing the wet sample into ceramic cup using a plastic spoon then dried it in an oven for 18 hours at $105^{\circ} \mathrm{C}$. After the sample was dry, it was cooled in a desiccator for $30 \mathrm{~min}$.

Prior to use, PG 990 atomic absorption spectrometry (AAS) made in Germany was calibrated according to manual instruction for the tool. Measurement of standard solution of metal and blanks as well as measurement of sample solution were then conducted. Measurement of $\mathrm{Pb}$ content in each organ solution placed in 10 $\mathrm{mL}$ volumetric flask was done in a wavelength of $283.3 \mathrm{~nm}$. During the standard measurement of metal, performance were checked periodically to ensure constant standard value.

\section{Data analysis}

All data were presented according to mean \pm standard deviation (SD) and analyzed using one-way ANOVA, followed by Fisher's exact test using Minitab 15. Result was considered significantly difference if $\mathrm{P}<0.05$.

\section{RESULTS AND DISCUSSION}

\section{Results}

Depuration method through the immersion of CGL in the culture media successfully affected the accumulation of $\mathrm{Pb}$ in various organs of experimental fish. In general, the results in this study indicate that the parameter of water quality such as dissolved oxygen, $\mathrm{pH}$, and temperature was still in the range of tolerance to ensure the maintenance of red tilapia fish. Observation on the behavior of experimental fish in all treatments showed a normal result. The study was conducted during the rainy season. The average water temperature during the study was fluctuated, the lowest was at $24.1{ }^{\circ} \mathrm{C}$ while the highest was at $25.8{ }^{\circ} \mathrm{C}$. In average, the lowest dissolved oxygen content was $5.00 \mathrm{mg} / \mathrm{L}$ and the highest was $6.76 \mathrm{mg} / \mathrm{L}$. The range of $\mathrm{pH}$ in vthe rearing media was 5.00-6.73.

\section{Depuration of $\mathrm{Pb}$ from muscle}

$\mathrm{Pb}$ content in the muscle of experimental fish before treatment was equal at $3.026 \pm 1.43 \mathrm{mg} / \mathrm{kg}$ $(\mathrm{H}-0)$. Along with the increasing CGL immersion period, $\mathrm{Pb}$ concentration in all experimental fish muscle decreased (except in control). The decrease in $\mathrm{Pb}$ concentration has occurred since d-3, that was observed at concentration of $30 \mathrm{~g} / \mathrm{L}$ and $40 \mathrm{~g} / \mathrm{L}$ and was significantly different from other treatments (Figure 1).

\section{Depuration of $\mathrm{Pb}$ from liver}

Before treatment, lead concentration in the liver of experimental fish was $0.039 \pm 0.09$ $\mathrm{mg} / \mathrm{kg}$. Moreover, all concentrations showed significantly different result against control since d-3 and d-7. Increasing concentration of

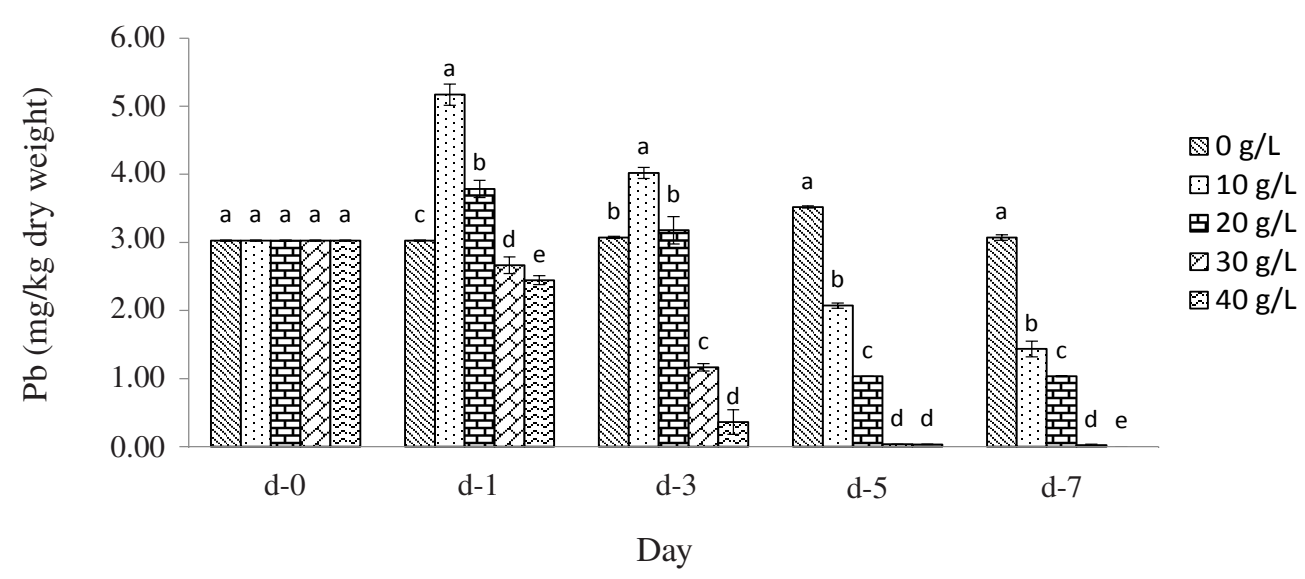

Figure 1. Concentration of $\mathrm{Pb}$ in the muscle of red tilapia Oreochromis sp. (mean $\pm \mathrm{SD})$. Different letter above the bar chart denotes significantly different results $(\mathrm{P}<0.05)$. 


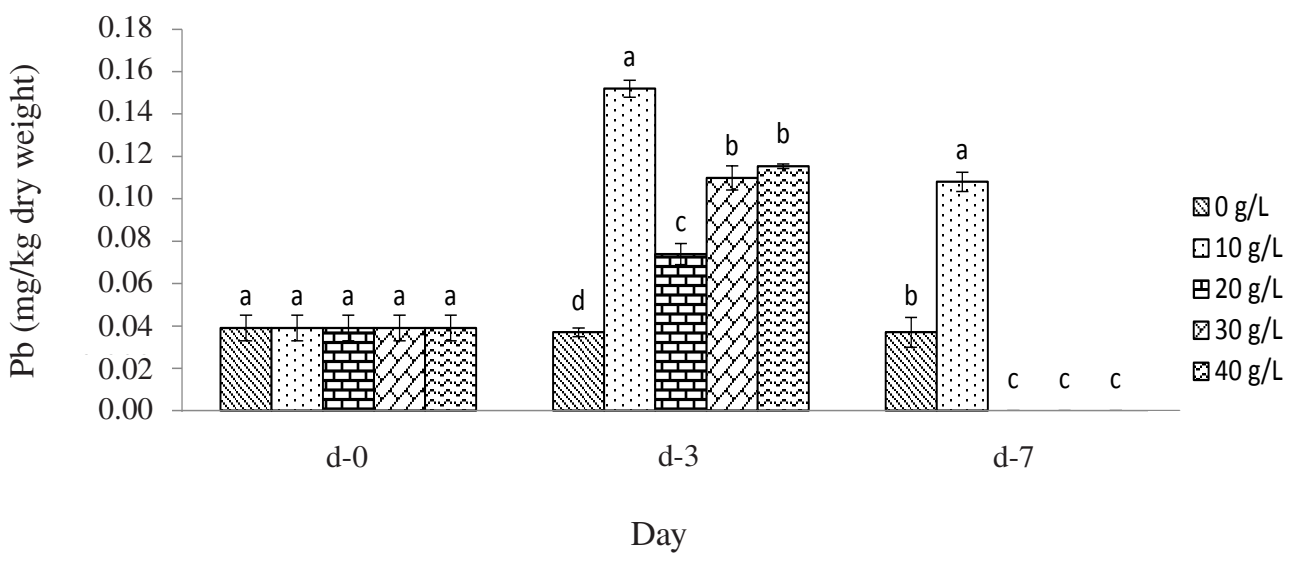

Figure 2. Concentration of $\mathrm{Pb}$ in the liver of red tilapia Oreochromis sp. (mean $\pm \mathrm{SD}$ ). Different letter above the bar chart denotes significantly different results $(\mathrm{P}<0.05)$.

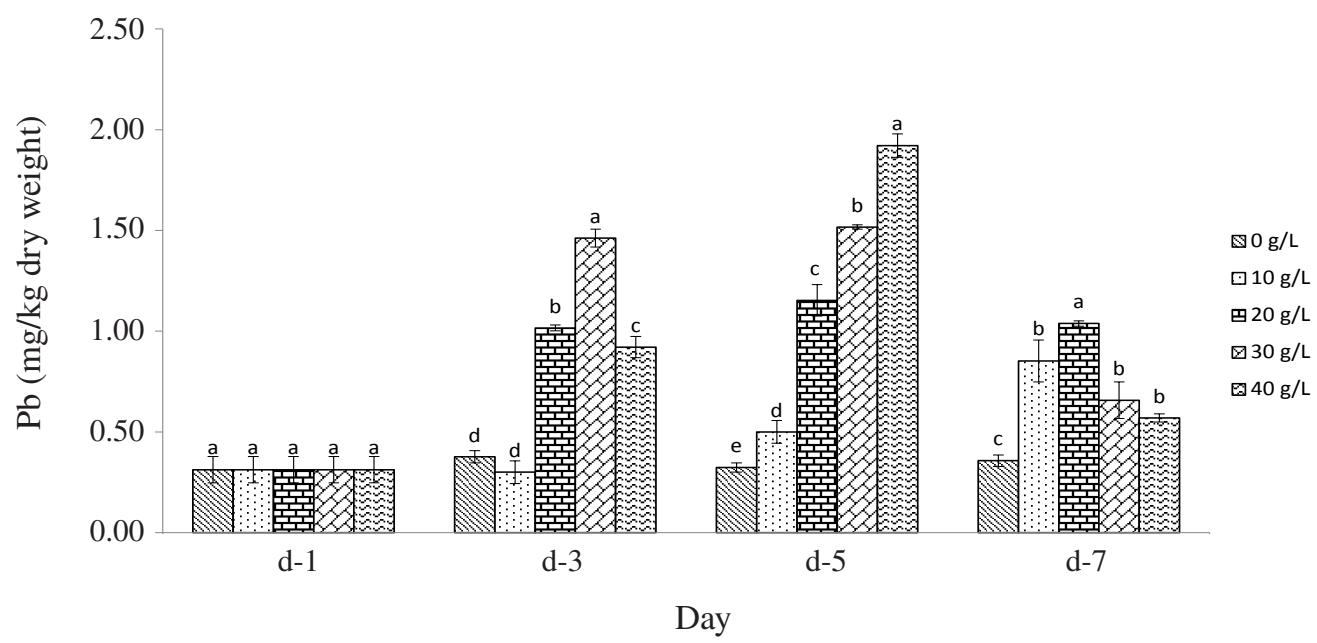

Figure 3. Concentration of $\mathrm{Pb}$ in the kidney of red tilapia Oreochromis sp. (mean $\pm \mathrm{SD})$. Different letter above the bar chart denotes significantly different results $(\mathrm{P}<0.05)$.

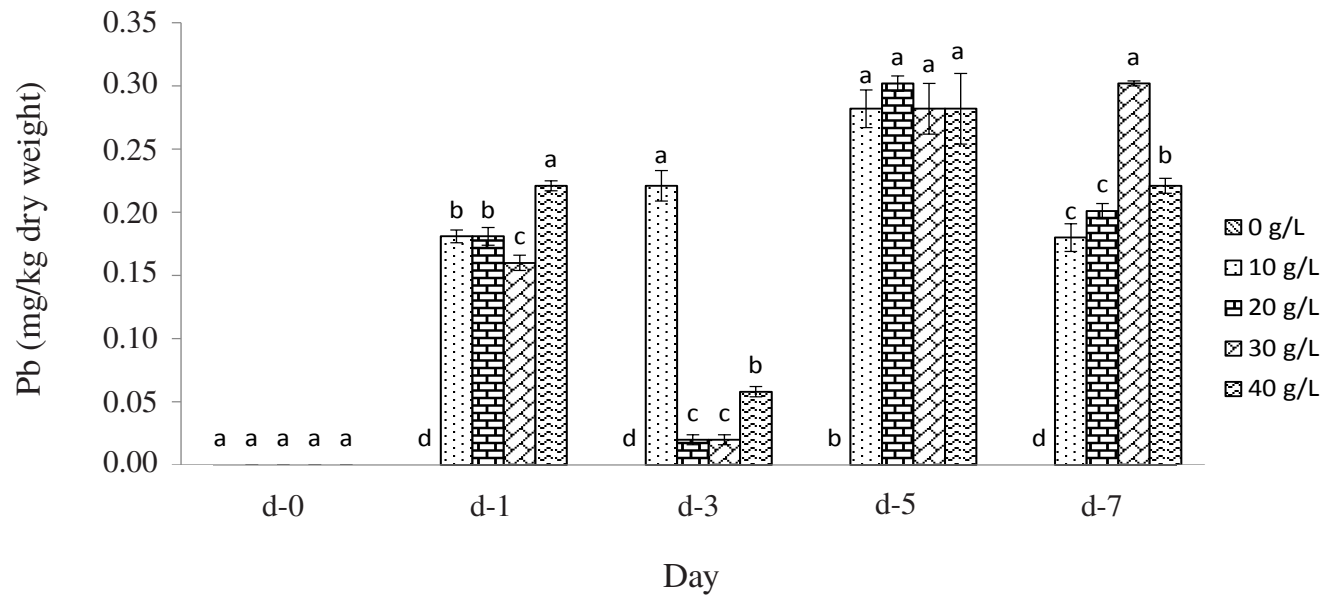

Figure 4. Concentration of $\mathrm{Pb}$ in the water culture media (mean $\pm \mathrm{SD}$ ). Different letter above the bar chart denotes significantly different results $(\mathrm{P}<0.05)$. 


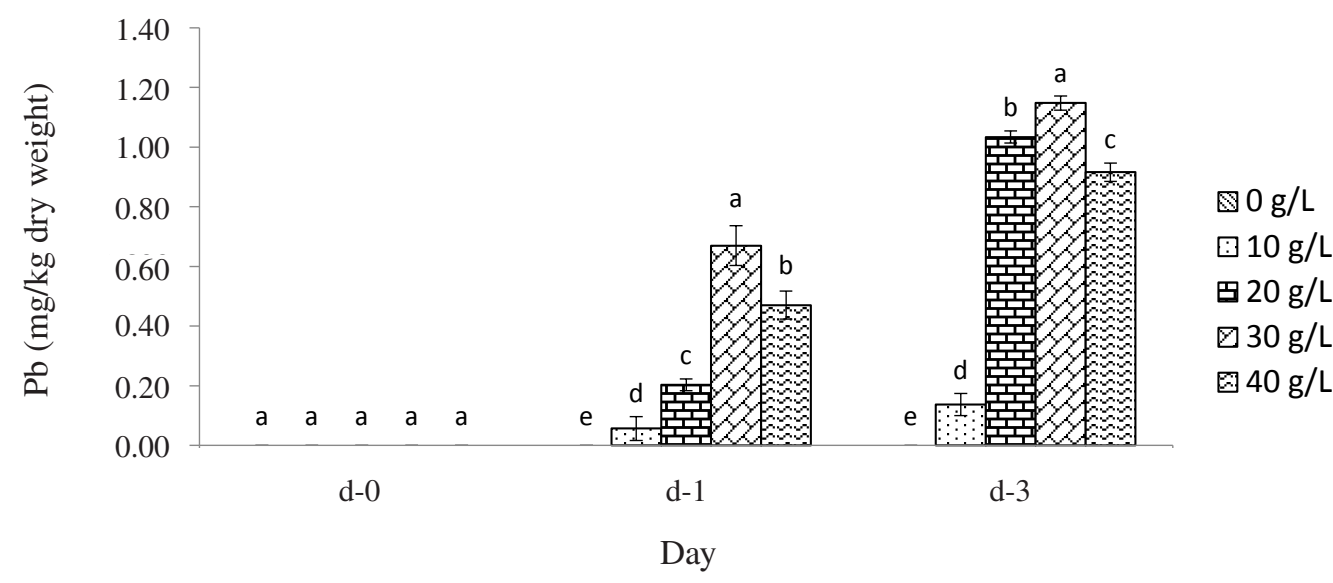

Figure 5. Concentration of $\mathrm{Pb}$ in compost (mean $\pm \mathrm{SD}$ ). Different letter above the bar chart denotes significantly different results $(\mathrm{P}<0.05)$.

$\mathrm{Pb}$ in $\mathrm{d}-3$ was observed which further decreased rapidly in $\mathrm{d}-7$ to $<0.012 \pm 0.00 \mathrm{mg} / \mathrm{L}$ (undetected), those were at concentration of 20,30 , and 40 $\mathrm{g} / \mathrm{L}$, proved that any concentrations of G. sepium leaves compost addition into the culture media resulted in significant effect in the liver of fish (Figure 2).

\section{Depuration of Pb from kidney}

At the beginning of culture period (d-0), concentration of $\mathrm{Pb}$ amounted of $0.312 \pm 0.23$ $\mathrm{mg} / \mathrm{kg}$ in the kidney of experimental fish. After the CGL addition in media, $\mathrm{Pb}$ concentration in the kidney increased since d-3 until d-5 of observation. Furthermore, a decline in concentration of $\mathrm{Pb}$ occurred in $\mathrm{d}-7$. This trend was found in all concentrations of CGL treatment (Figure 3), except in control where the amount of accumulated $\mathrm{Pb}$ did not decrease during the observation period.

\section{$\mathrm{Pb}$ in water}

At the beginning of observation (d-0), $\mathrm{Pb}$ was not detected in the water used in all treatments $\mathrm{Pb}(<0.012 \pm 0.00 \mathrm{mg} / \mathrm{L})$. However, the average concentration of $\mathrm{Pb}$ in all treatments (except controls) increased along with the culture period. At the end of the culture (d-7), the highest concentration of $\mathrm{Pb}$ was found in the media with CGL concentration of $30 \mathrm{~g} / \mathrm{L}$ while the lowest was in $10 \mathrm{~g} / \mathrm{L}$ (Figure 4).

\section{$\mathrm{Pb}$ in compost}

Observation of all concentration of treatment in $\mathrm{d}-0$ resulted in the same value, that was $<0.012 \pm 0.00$ (not detected). Moreover, along with the increasing compost immersion time in water of treatment media, $\mathrm{Pb}$ in all concentration of treatment (except controls) have increased since $\mathrm{d}-3$ and $\mathrm{d}-7$. The highest increasing occurred in $\mathrm{d}-7$. Above all, increase in concentration of $\mathrm{Pb}$ in compost showed significant difference between $\mathrm{Pb}$ concentration of $0 \mathrm{~g} / \mathrm{L}$ and $10 \mathrm{~g} / \mathrm{L}$; and $\mathrm{Pb}$ concentration of $20 \mathrm{~g} / \mathrm{L}, 30 \mathrm{~g} / \mathrm{L}$, and $40 \mathrm{~g} / \mathrm{L}$ (Figure 5).

\section{Discussion}

According to the measurement result of humic acid and fulvic acid used in CGL, it is known that $1.814 \mathrm{mg}$ of humic acid and $0.183 \mathrm{mg}$ of fulvic acid were contained in every $100 \mathrm{~g}$ of CGL. Humic acid and fulvic acid have the ability to form complex with metal ions (Fu et al., 2011). Exchange capacity of fulvic acid which is more than twice higher than that of humic acid causes fulvic acid to be easier to penetrate cells and spread throughout the living organisms (Giannis et al., 2009). Due to the different nature of the two types of organic active matter, fulvic acid plays a greater role in the mechanism of depuration in organ cells through immersion method in the media, yet the role of humic acid outside the cell organ of experimental fish is also important. Fulvic acid enters the body of test fish through the water pumping process over the gills, through the water drunk by the test fish and direct penetration through the skin. Moreover, humic acid enters the fish while fish drinks the water.

As fulvic acid can easily enter through the gills, fulvic acid enters the gill cell by a mechanism of diffusion, ion pump and ion channel (Soto et al., 2010). The entrance of fulvic acid (by diffusion and ion pump) is in the form of respiratory cells contained in the secondary gill lamellae of fish 
and specific path in lamellar membrane, the path is directly connected to the blood stream gills and later into the blood.

Process of water intake directly from the fish mouth causes humic acid and fulvic acid enter the fish body. About $80 \%$ of organic compounds become inactive inside the fish stomach which has $\mathrm{pH}$ of $2-4$; thus, $\mathrm{Pb}$ in the stomach will change into divalent form. The presence of humic acid and fulvic acid in the stomach will prevent $\mathrm{Pb}$ to change into divalent form. Its their active groups, those are carboxyl and phenolic, bind $\mathrm{Pb}$ and avoid from being absorbed by the stomach cells. In the intestines, fulvic acid can directly enter the digestive cells, that is entering through mikrovilli cells by diffusion, through ion pumps and through ion channels. Chelation mechanism of $\mathrm{Pb}$ by fulvic acid in mikrovilli cell of fish intestines is similar to the mechanism in gill cells (Soto et al., 2010). Pb chelated through the intestine is secreted back by mikrovilli cells out of the cell (in the intestines) to be excreted with feces and part of fulvic acids enter the blood. In the intestine, humic acid work more dominant than fulvic acid due to the nature of humic acid which is soluble in alkaline $\mathrm{pH}$. Thus, $\mathrm{Pb}$ will be strongly bound through chelation mechanism then will be excreted through feces.

Similar to the statement of Orsetti et al. (2007), humic acids are capable to form a chelate with heavy metals with strong bond. The occurrence of this mechanism was proven by the increase in the $\mathrm{Pb}$ content in the water of culture media in all treatments. Increasing concentrations of $\mathrm{Pb}$ on the $\mathrm{d}-7$ of treatment was found in concentration of $30 \mathrm{~g} / \mathrm{L}$ (the highest) and $10 \mathrm{~g} / \mathrm{L}$ (the lowest). This finding proved that the cation exchange capacity (CEC) of CGL has a maximum limit to bind $\mathrm{Pb}$ from water of culture media. In addition, CGL area that was in contact with culture media (such as compost layer that was too thick), also became the reason of decrease in $\mathrm{Pb}$ concentration in water of culture media at a concentration of 40 $\mathrm{g} / \mathrm{L}$ on $\mathrm{d}-7$.

Measurements of $\mathrm{Pb}$ in compost also showed significant results against control. Moreover, measurement result on CGL immersed in the culture media during the study indicated that all CGL contained $\mathrm{Pb}$. This finding proved that CGL was able to bind $\mathrm{Pb}$ released into the maintenance water and later performed the chelation process; thus, $\mathrm{Pb}$ was not re-absorbed by the experimental fish. These results are consistent with the statement of Osman et al. (2009) and Deen et al. (2009) that the addition of fulvic acid and humic acid into the culture media will reduce the absorption and accumulation of heavy metals into the fish body. The highest concentration of $\mathrm{Pb}$ in CGL was 30 $\mathrm{g} / \mathrm{L}$, followed by concentration of $20 \mathrm{~g} / \mathrm{L}, 40 \mathrm{~g} / \mathrm{L}$, and $10 \mathrm{~g} / \mathrm{L}$. The result of these measurements explains that organic ligand has a maximum capacity to bind metal. Wu et al. (2008) added that $\mathrm{Pb}$ ion and organic matter of compost will interact to form complex compound and chelate according to the amount of active ingredient of chelating agents.

Fluctuation of $\mathrm{Pb}$ contents in the culture media during the observation time indicated that process of which $\mathrm{Pb}$ was released from body of experimental fish into the media and later, chelation process of $\mathrm{Pb}$ from the water of culture media by CGL had occurred. Complex compounds will be strongly bound when the coordination compound, of which its $\mathrm{Pb}$ ion, is bound by ligand with two or more bonds (Orsetti et al., 2013). Adsorption method for $\mathrm{Pb}$ is generally based on the interaction between $\mathrm{Pb}$ ion and functional groups in humic acid and fulvic acid through the interaction of complex formation. Coordination complex is defined as cation compound which has empty orbital (central atom) with anion having one electron pairs (ligands) bind one another by sharing several lone electrons of the ligand (Orsetti et al., 2013). This mechanism occured in the water of culture media; thus, $\mathrm{Pb}$ was strongly bound in CGL and will not be released back into the water of culture media. Phenomenon of an increase of $\mathrm{Pb}$ in water of culture media and CGL during the research proved that immersion of CGL in the culture media of red tilapia Oreochromis sp. led to depuration process of $\mathrm{Pb}$ in the organs of experimentsl fish.

In the blood, fulvic acid will be more effective in binding $\mathrm{Pb}$. There are two mechanisms of fulvic acid in the body. First, outside the cell, fulvic acid directly performs chelation which further will be transported to the secretory organ. Second, inside the cell, fulvic acid helps or together with methalloprotein (MT) in binding and carrying $\mathrm{Pb}$ out of the cells. Fulvic acid follows the circulatory system; thus, blood cells carries and transports fulvic acid to the detoxification organ (liver) and secretion organ (kidney). Similar mechanism is also performed by fulvic acid in the liver and kidney; therefore, the role of liver as detoxifying organ becomes more optimal (Soto et al., 2010). As proven in this research result, accumulation 
of $\mathrm{Pb}$ in the liver of experimental fish of all treatments on $\mathrm{d}-0$ (the beginning of observation) resulted in the same concentration, that was $0.039 \pm 0.09 \mathrm{mg} / \mathrm{kg}$. After the treatment of CGL immersed in water of culture media, there was increase of $\mathrm{Pb}$ in the liver on $\mathrm{d}-3$, yet accumulation of $\mathrm{Pb}$ decreased on $\mathrm{d}-7$. This trend was found in all treatments except control (concentration of $0 \mathrm{~g} / \mathrm{L}$ ) where the amount of $\mathrm{Pb}$ accumulation from the liver did not decrease. CGL immersion concentration of $20 \mathrm{~g} / \mathrm{L}, 30 \mathrm{~g} / \mathrm{L}$, and $40 \mathrm{~g} / \mathrm{L}$ was selected as effective concentration to depurate $\mathrm{Pb}$ in liver of red tilapia Oreochromis sp. through the media. It was observed that concentration of $20 \mathrm{~g} / \mathrm{L}, 30 \mathrm{~g} / \mathrm{L}$, and $40 \mathrm{~g} / \mathrm{L}$ was able to depurate $\mathrm{Pb}$ from $0.039 \pm 0.09 \mathrm{mg} / \mathrm{kg}$ to $<0.012 \pm 0.00 \mathrm{mg} /$ $\mathrm{kg}$ (not detected) on d-7 of observation. Increase and decrease in the concentration of $\mathrm{Pb}$ in fish liver during the study proves that immersion of CGL in the culture media can improve the liver performance and depurate $\mathrm{Pb}$ from the liver of red tilapia Oreochromis sp.

Result of measurement in the kidney also showed the same tendency toward the liver. On $\mathrm{d}-0$, the ammount of accumulated $\mathrm{Pb}$ in fish kidney of all treatments was the same, equaled to $0.312 \pm 0.23 \mathrm{mg} / \mathrm{kg}$. After treatment of CGL immersed in water of culture media, there was increase of $\mathrm{Pb}$ in kidney, in average, on $\mathrm{d}-3$ and d-5 of observation, but the accumulation of $\mathrm{Pb}$ further decreased on d-7. This trend was found in all treatments (Figure 3), except in control (concentration of $0 \mathrm{~g} / \mathrm{L}$ ). Fluctuation of $\mathrm{Pb}$ concentration in fish kidney which occurred in several concentration treatment and at several time of observation showed that the addition of CGL into the culture media can improve the function and performance of kidney in eliminating $\mathrm{Pb}$ that has been accumulated in the body of red tilapia. This phenomenon also explained that the process of $\mathrm{Pb}$ elimination through the kidney became effective with CGL immersion method.

It was found from in the preliminary research that the amount of $\mathrm{Pb}$ remained in the muscle of experimental fish already contaminated with $\mathrm{Pb}$ and had been naturally depurated with continuous running water was $3.026 \pm 1.43 \mathrm{mg} /$ $\mathrm{kg}$ (dry weight) of which this amount cannot be naturally re-depurated. Based on the quality standard, maximum $\mathrm{Pb}$ content in processed fish is $0.3 \mathrm{mg} / \mathrm{kg}$ (ISO 2009). On d-0 (the beginning of observation), $\mathrm{Pb}$ contained in the muscle of red tilapia amounted to $3.026 \pm 1.43 \mathrm{mg} / \mathrm{kg}$.

Based on overall observations, the average accumulation of $\mathrm{Pb}$ in fish muscle in all treatment concentrations tended to decline. In general, decline occurred from d-5 until d-7. However, concentration of $\mathrm{Pb}$ in control during the observation relatively did not decrease. The best concentration of CGL in depurating $\mathrm{Pb}$ in the muscle of red tilapia through the medium was $30 \mathrm{~g} / \mathrm{L}$ and $40 \mathrm{~g} / \mathrm{L}$. Based on the observation result, concentration of $30 \mathrm{~g} / \mathrm{L}$ and $40 \mathrm{~g} / \mathrm{L}$ was able to depurate $\mathrm{Pb}$ accumulated in the muscle of red tilapia, from being not safe to being safe for human consumption.

Decrease in $\mathrm{Pb}$ concentration in the muscle have occurred since d-3, but the concentration was still above the quality standard of safe for human consumption $(<0.3 \mathrm{mg} / \mathrm{kg})$. Significant declines continued until d-5 and d-7. Concentration of $30 \mathrm{~g} / \mathrm{L}$ decreased to $0.035 \pm 0.01 \mathrm{mg} / \mathrm{kg}$ on d -5 of observation and further decreased to $0.023 \pm 0.06$ $\mathrm{mg} / \mathrm{kg}$ on d-7. Concentration of $40 \mathrm{~g} / \mathrm{L}$ decreased to $0.032 \pm 0.02 \mathrm{mg} / \mathrm{kg}$ on $\mathrm{d}-5$ and decreased again to $<0.012 \pm 0.00 \mathrm{mg} / \mathrm{kg}$ (not detected) on $\mathrm{d}-7$. Decrease in $\mathrm{Pb}$ concentration in muscle was due to increase in function of liver and kidney. Moreover, this decline also proves that there is activity of humic acid and fulvic acid as chelating agents of $\mathrm{Pb}$ in the body of red tilapia Oreochromis sp. Decrease in $\mathrm{Pb}$ concentration may be started since the rapid decline of $\mathrm{Pb}$ in blood of experimental fish due to elimination process of $\mathrm{Pb}$ which occurred effectively through the kidney. Furthermore, the occurrence of well chelation mechanism on $\mathrm{Pb}$ through the immersion of compost, so that $\mathrm{Pb}$ was released into the water of culture media and did not go back into the body of experimental fish, can also be the reason of declining concentration of $\mathrm{Pb}$ from the muscle of red tilapia Oreochromis sp.

In general, results of statistical analysis show that all test parameters observed during the observation period were significantly different from control. This condition proved that all concentrations of treatment (except control) affected the depuration process of $\mathrm{Pb}$ from the organs of experimental fish. Significantly difference result among the treatment concentration in each observation time indicated that different immersion concentrations of CGL will lead to different depuration effect on $\mathrm{Pb}$ accumulated in the organs of fish. Observation results described above proved that CGL was able to perform depuration of $\mathrm{Pb}$ from the body of red tilapia Oreochromis sp. through the media. Concentration of $30 \mathrm{~g} / \mathrm{L}$ was found to be the best 
concentration of CGL in performing depuration of $\mathrm{Pb}$ from the body of red tilapia Oreochromis sp. through media.

\section{CONCLUSION}

Based on the results, CGL immersed in the maintenance medium was able to depurate $\mathrm{Pb}$ in the muscle of tilapia Oreochromis sp. up to a safe limit for human consumption $(<0.012$ or not detected). The best concentration during five days of immersion was $30 \mathrm{~g} / \mathrm{L}$. The use of CGL with a five-day immersion method should be recommended for providing treatment of fish farmed in the post-mine of tin in kolong, Bangka Belitung Province, before the fish is released to the market.

\section{ACKNOWLEDGEMENTS}

The authors are grateful to Ministry of Research, Technology and Higher Education for funding this research. Special gratitude is also given to the Laboratory of Environment, Department of Aquaculture, Bogor Agricultural University for providing facilities during research.

\section{REFERENCES}

Christopher JM, Andrew LR, David TW. 2013. Hydroxyl radical production by $\mathrm{H}_{2} \mathrm{O}_{2}$ mediated oxidation of $\mathrm{Fe}$ (II) complexed by suwannee river fulvic acid under circumneutral freshwater conditions. Environmental Science Technology 47: 829-835.

Deen AEL, Zaki MS, Osman HA. 2009. Role of fulvat acid on reduction of cadmium toxicity on Nile tilapia Oreochromis niloticus Egypt. World Applied Sciences Journal 1: 133-140.

Fu F, Wang Q. 2011. Removal of heavy metal ion from wastewaters: A review. Journal of Environmental Management 92: 407-418.

Giannis A, Nikolaou A, Pentari D, Gidarakos E. 2009. Chelating agent-assisted electrokinetic removal of cadmium, lead and copper from contaminated soils. Environmental Pollution 157: 3379-3386.

Henny C, Evi S. 2009. Limnological characteristics of tin mine pit lakes in Bangka Island. LIMNOTEK 16: 119-131.

Henny C. 2011. Mine pit lakes in Bangka island: water quality problem and alternative solution for the utilization. Oseanografi dan Limnologi di Indonesia, LIPI 37: 119-138.
Hermana J, Nurhayati E. 2010. Removal of $\mathrm{Cr}^{3+}$ and $\mathrm{Hg}^{2+}$ using compost derived from muncipal solid waste. Environment Research Journal20: 257-261.

Kucasoy G, Guvener Z. 2009. Efficiency of compost in the removal of heavy metals from the industrial wastewater. Environmental Geology 57: 291-296.

Nebbioso A, Alessandro P. 2012. Advances in humeomics: enhanced structural identification of humic molecules after size fractionation of a soil humic acid. Analytica Chimica Acta 720: 77-90.

Orsetti S, Quiroga MM, Andrade EM. 2007. Binding of $\mathrm{Pb}$ (II) in sistem humic acid. Environmental Chemistry 65: 2313-2321.

Orsetti S, Brown JLM, Andrade EM, Molina F. 2013. Pb (II) binding to humic substances: An equilibrium and spectroscopic study. Environmental Science Technology47: 83258333.

Osman HAM, Ibrahim TB, Ali AT, Derwa HIM. 2009. Field application humic acid against the effect of cadmium pollution on cultured tilapia Oreochromis niloticus. World Applied Sciences Journal 6: 1569-1575.

Piccolo, A. 2002. The supramolecular structures of humic substances: A novel understanding of humus chemistry and implications in soil science. Advanced Agronomy 75: 57-78.

Prasetiyono E. 2013. Comparative Study of compost made from plant leaves with different $\mathrm{C} / \mathrm{N}$ ratio to adsorption lead heavy metal in fish culture Media. AKUATIK-Jurnal Sumberdaya Perairan 7: 6-12.

Priyanto N, Dwiyitno, Ariyani F. 2008. Heavy metal residues $(\mathrm{Hg}, \mathrm{Pb}, \mathrm{Cd}$, and $\mathrm{Cu})$ in fish, water, and sediment at Cirata Reservoir, West Java. Jurnal Pascapanen dan Bioteknologi Kelautan dan Perikanan 3: 71-78.

[SNI] Standar Nasional Indonesia. 2009. Batas maksimum cemaran logam berat dalam pangan: 7387. Jakarta: Badan Standarisasi Nasional (BSN).

Soto M, Marigomez I, Cancio I. 2010. Biological Aspects of Metal Accumulation and Storage. Basque Country: Zoology and Animal Cell Biology. Dept. Cell biology and histology. Leioa: University of the Basque.

Sujitno S. 2007. Sejarah Timah di Pulau Bangka. Pangkalpinang: PT. Tambang Timah Tbk.

Wu Y, Zhang S, Guo X, Huang H. 2008. Adsorption of chromium (III) on lignin. Bioresource Technology 99: 7709-7715. 